\title{
GMR
}

\section{Detection of protein and DNA damage induced by elevated carbon dioxide and ozone in Triticum aestivum L. using biomarker and comet assay}

\author{
E. Abdelhaliem ${ }^{1,2}$ and A.A. Al-Huqail ${ }^{2}$ \\ ${ }^{1}$ Plant Genetic and Molecular Cytogenetic, Botany Department, \\ Science College, Zagazig University, Sharkia, Egypt \\ ${ }^{2}$ Botany and Microbiology Department, Science College, \\ King Saud University, Riyadh, Saudi Arabia \\ Corresponding author: E. Abdelhaliem \\ E-mail: ekram@ksu.edu.sa / ekram.esa@gmail.com
}

Genet. Mol. Res. 15 (2): gmr. 15028736

Received April 27, 2016

Accepted June 13, 2016

Published June 30, 2016

DOI http://dx.doi.org/10.4238/gmr.15028736

\begin{abstract}
This study was designed to compare the genetic effects of elevated carbon dioxide $\left(\mathrm{CO}_{2}\right)$ and ozone $\left(\mathrm{O}_{3}\right)$, alone or in combination, under irrigated and non-irrigated conditions on proteins and DNA of wheat (Triticum aestivum L.). Sodium dodecyl sulfatepolyacrylamide gel electrophoresis (SDS-PAGE), isozymes, random amplified polymorphic DNA (RAPD), and comet assays were used. SDS-PAGE analysis revealed distinctive polymorphisms (100\%) based on the number of polypeptide bands (169) with molecular weights ranging from 300.0 to $24.00 \mathrm{kDa}$, band intensity, appearance, and loss of bands when compared with control samples. Six isozymes, malate dehydrogenase, amylase, leucine-aminopeptidase, esterase, peroxidase, and catalase, generated $100 \%$ polymorphism values based on zymogram number, relative front, and optical intensities. RAPD revealed 276 DNA bands with a distinctive polymorphism value of
\end{abstract}


92.31\% based on the number of amplified DNA products, ranging from 45 to $1100 \mathrm{bp}$, and band intensity. In the comet assay, the highest extent of nuclear DNA damage was observed as tail length $8.70 \mu \mathrm{m}$, tailed DNA $8.01 \%$, and tail moment unit 34.18 in non-irrigated $\mathrm{O}_{3}$-treated wheat nuclei. These results show that $\mathrm{O}_{3}$-treatment alone induced high levels of oxidative protein and DNA damage in wheat plant, especially in a non-irrigation system. Interestingly, $\mathrm{CO}_{2}$ in combination with $\mathrm{O}_{3}$ could ameliorate the negative impact of $\mathrm{O}_{3}$-oxidative stress. This study shows that protein and DNA biomarkers, and the comet assay, could be used for the reliable estimation of genotoxicity following the exposure of economic crop plants to air pollutants.

Key words: Elevated $\mathrm{CO}_{2}$ and $\mathrm{O}_{3}$; SDS-PAGE; Isozymes; RAPD-PCR; Comet assay; Triticum aestivum

\section{INTRODUCTION}

In recent years, the global climate has undergone significant changes, mainly due to increased atmospheric concentrations of both greenhouse gases, carbon dioxide $\left(\mathrm{CO}_{2}\right)$ and ozone $\left(\mathrm{O}_{3}\right)$. Levels of greenhouse gases have increased significantly since pre-industrial times, owing to human activity, and are predicted to continue to rise in the future (IPCC, 2013). Rising $\mathrm{CO}_{2}$ levels affect most crucial biological processes, as well as the expression of genetic variation relative to the biological processes' traits and other key secondary metabolic processes in plants (Xu et al., 2015). Those authors reported that genes expressed under conditions of elevated $\mathrm{CO}_{2}$ might encode proteins with substantial functional changes, including the increased expression of a subset of genes encoding stress-related proteins, and decreased expression of genes related to chloroplast functions and other photosynthetic processes. However, gene expression in response to $\mathrm{CO}_{2}$ fumigation may depend on the developmental stage at the time of sampling, and the physiological condition of the plant. Wroblewitz et al. (2013) concluded that $\mathrm{CO}_{2}$ would affect the structural composition of proteins and, consequently, the nutritional value of maize, wheat, and barley grain. In addition, a study by Liao et al. (2011) showed that high-pressure $\mathrm{CO}_{2}$ induced leakage and the subsequent loss of proteins and DNA from Escherichia coli.

Conversely, $\mathrm{O}_{3}$, which is a potent air pollutant and greenhouse gas, has been recognized as a major factor influencing global climate change. However, the current increasing trend in the background level of $\mathrm{O}_{3}$ can adversely affect plants and other living organisms, and a more severe threat to natural and cultivated plants is projected in the near future (Tripathi and Agrawal, 2012). $\mathrm{O}_{3}$ is considered to be the most phytotoxic regional scale air pollutant owing to its high oxidative capacity, which involves the induction of reactive oxygen species (ROS) in plant cells. ROS interfere with cellular macromolecules and basic physiological functions (Mishra et al., 2013). $\mathrm{O}_{3}$ enters the cell through the cell wall and plasma membrane, where it is rapidly converted into different ROS, which are highly toxic and induce changes in proteins, and cause oxidative DNA lesions (Mishra et al., 2013). $\mathrm{O}_{3}$ also induces the up-regulation of antioxidant defense systems in plants (Olbrich et al., 2009).

As atmospheric $\mathrm{CO}_{2}$ and $\mathrm{O}_{3}$ levels are rising at an alarming rate, several experiments have been performed in recent years to examine their effect on the morphology and physiology 
of some crop plants such as soybean, peanut, and wheat (Mishra et al., 2013). However, those studies have neglected to assess the impact of these greenhouse gases alone and in combination on electrophoretic protein and DNA levels. Studies on these crop plants have clearly established that elevated $\mathrm{CO}_{2}$ partially or fully compensates for the negative effects of $\mathrm{O}_{3}$. Elevated $\mathrm{CO}_{2}$ reduces stomatal conductance and thereby ameliorates $\mathrm{O}_{3}$-induced oxidative damage by suppressing its entry through stomata (Mishra et al., 2013).

Plants are exposed to a wide range of environmental pollutants and can therefore be used to monitor the presence of chemical and physical mutagens in polluted habitats. Plants are unique in their ability to serve as in-situ monitors of toxicity induced by environmental pollutants that cause genotoxic and oxidative stress inflicting protein and DNA damages, which can reduce plant genome stability, growth, and productivity (Maluszynska and Juchimiuk, 2005). Wheat (Triticum aestivum L.) was one of the first domesticated food crops and is now the third most important crop worldwide. Almost two-thirds of the world's population depends on this crop as their primary supply of nutrition (Monneveux et al., 2012). Additionally, wheat is considered the most $\mathrm{O}_{3}$ sensitive crop, which is likely to be due to $\mathrm{O}_{3}$ levels peaking during its growing season (Mishra et al., 2013).

Biochemical assays related to protein-based markers such as non-enzymatic proteins (storage proteins) and enzymatic proteins (isozymes) detect variation in the primary conformation of the proteins resulting from variation in the DNA coding sequences and active structural genes (Karaca, 2013). Therefore, any variations in the size, amino acid sequence, and variant forms of proteins arise from variations in the nucleotide sequences of genes. Protein-based methods sodium dodecyl sulfate-polyacrylamide gel electrophoresis (SDSPAGE) is the most cost effective, simple and extensively used biochemical techniques for describing the seed protein variation and the analysis of genetic structure of crop germplasm (Kumar and Tata, 2010). Furthermore, SDS-PAGE is considered a reliable technology that can be used to evaluate and characterize banding patterns of seed-storage proteins in affected and unaffected plants (Mondini et al., 2009). Conversely, electrophoretic SDS-protein profiles and protein polymorphisms have already been widely applied to the study of genetic variability, possible mutagenic potential, and oxidative damage occurring as a result of genotoxic pollutants in storage proteins of different plant species (Abdelhaliem et al., 2013; Al-Huqail and Abdelhaliem, 2015).

Conversely, isozyme analysis is used to detect molecular changes occurring in crop germplasm exposed to genotoxic environmental stress (Hailu et al., 2014). Isozymes are proteins that have similar or identical catalytic activity, but differ in molecular weight and form due to differences in amino acid residues, kinetics, substrate affinity, number of subunits, electric charge, and/or electrophoretic mobility (Karaca, 2013; Padmanaban et al., 2013). Isozymes arise from multiple gene loci that code for structurally distinct polypeptide chains. They are encoded by different genes and expressed at a distinct stage of plant development (Karaca, 2013; Hailu et al., 2014). Differential expression of isozymes is associated with different developmental stages, tissue specificity, and stress factors (Padmanaban et al., 2013). Expressional analysis of isozymes is useful when studying the response of plants to biotic and abiotic stress conditions; for example, affected plants may express different forms of oxidative isozymes.

In the study of genotoxicity, advances in molecular biology have led to the development of a number of selective and sensitive assays for DNA-based analysis. Molecular assays such as random amplified polymorphic DNA based polymerase chain reaction (RAPD-PCR) and 
molecular cytogenetic assays such as single-cell gel electrophoresis (comet assay) are two qualitative and quantitative methods that have been used to detect DNA damage and mutation (e.g., rearrangements, point mutations, small inserts or deletions, ploidy changes, and single and double DNA strand breaks). The RAPD-PCR technique is used to study the genotoxic effects of environmental stress, and can be used to evaluate how environmental pollutants modify the structure of DNA in living organisms. This technique can detect nucleotide sequence polymorphisms that are randomly distributed throughout the genome, in both coding and noncoding regions (Atienzar and Jha, 2006). In addition, differences in RAPD profiles have been used to detect genetic variation and to evaluate the genotoxicity of environmental pollutants (Gjorgieva et al., 2012; Cansaran-Duman et al., 2015).

In recent years, a novel molecular cytogenetic-based assay, termed single cell gel electrophoresis (SCGE) or the comet assay, has been applied to plant cells to investigate the cellular response to genotoxic agents, and to biotic and abiotic stresses that lead to oxidative DNA damage (Ventura et al., 2013). The comet assay is a common method used to detect DNA damage (e.g., single and double-strand breaks, oxidative-induced base damage, and DNADNA/DNA-protein cross-linking) by electrophoresis. The basic principle of this assay is the identification of DNA lesions in plant cells induced by genotoxic agents. These DNA lesions migrate as a comet tail from isolated nuclei embedded in single-cell agarose gel electrophoresis while the remaining nuclear scaffold appears as the comet head (Dikilitas et al., 2009). The average proportion of DNA in the tail is taken as a measure of DNA damage. There has been increasing interest in the comet assay for use in various in vitro and in vivo studies to evaluate DNA damage and repair (Ventura et al., 2013). The study of Tai et al. (2010) used the comet assay to measure the DNA damage in Populus tremuloides clones exposed to elevated $\mathrm{O}_{3}$ in the presence and absence of elevated $\mathrm{CO}_{2}$ and suggested that the variation in cellular responses to DNA damage between aspen clones may contribute to $\mathrm{O}_{3}$ tolerance or sensitivity.

The objective of the present study was to ascertain how cellular macromolecules such as proteins, isozymes, and DNA in agricultural crops such as wheat grains are affected by elevated $\mathrm{CO}_{2}$ and $\mathrm{O}_{3}$, on their own and in combination under two irrigation systems. This should provide information on wheat responses at biochemical and molecular levels and demonstrate how protein and DNA technology may permit the modification of these responses through genetic manipulation.

\section{MATERIAL AND METHODS}

\section{Experimental area and plant materials}

Grains of wheat (T. aestivum L. cv. Giza 168) obtained from the Agronomy Research Department, Field Crops Institute, Agriculture Research Center, Giza, Egypt, were used as the plant material in this study. Wheat grains were screened for viability and uniformity in size and then divided into eight groups. Wheat grains of each group were sterilized and sown in earthenware pots (30 $\mathrm{cm}$ high $\times 20 \mathrm{~cm}$ diameter) containing soil obtained from top soil in the field, until the second foliage leaf appeared. Then, they were transferred to eight cylindrical open-top fumigation chambers (OTCs) 1.5 and $1.8 \mathrm{~m}$ in height following the study design described by Mulchi et al. (1992). Plants were exposed to elevated $\mathrm{CO}_{2}$ and $\mathrm{O}_{3}$ by fumigation, on their own and in combination, under two irrigation systems (irrigated versus non-irrigated) as previously described (Ephratha et al., 2011). Untreated samples were used as controls. 
Next, plants remained exposed to all treatments in OTCs until they reached maturity and the harvest stage. The untreated and treated grains were harvested from five plants per pot and were thoroughly cleaned to ensure that all foreign particles are removed. Samples were then air-dried and subjected to biochemical, molecular, and comet analyses. Seeds were used in this study instead of leaves to avoid the accumulation of staining inhibitors in leaves due to the effects of $\mathrm{CO}_{2}$ and $\mathrm{O}_{3}$ treatments (Sliwinska et al., 2009).

\section{Experimental design}

\section{Treatments}

Four OTCs were designed for four treatments under the irrigation system (I) at $100 \%$ crop evapotranspiration during the entire season. Irrigation units were utilized to maintain soil moisture levels near field capacity in all pots by daily irrigation with about $12-20 \mathrm{~mm}$ water: 1 ) elevated $\mathrm{CO}_{2}$ treatment at $\left.580 \mathrm{ppm}\left(\mathrm{ICO}_{2}\right) ; 2\right)$ elevated $\mathrm{O}_{3}$ treatment at $\left.120 \mathrm{ppb}\left(\mathrm{IO}_{3}\right) ; 3\right) 580$ ppm $\mathrm{CO}_{2}+120 \mathrm{ppb} \mathrm{O}_{3}$ treatment, I $\left(\mathrm{CO}_{2}+\mathrm{O}_{3}\right)$; 4) control-OTC (ICF). The other four OTCs were designed for the same treatments, but were under a non-irrigation system (NI). The non-irrigated chambers were subjected to water stress conditions by withholding irrigation: 5) control-OTC (NICF); 6) $580 \mathrm{ppm} \mathrm{CO}+120 \mathrm{ppb} \mathrm{O}_{3}$ treatment $\mathrm{NI}\left(\mathrm{CO}_{2}+\mathrm{O}_{3}\right)$; 7) elevated $\mathrm{O}_{3}$ treatments at $\left.120 \mathrm{ppb}\left(\mathrm{NIO}_{3}\right) ; 8\right) \mathrm{CO}_{2}$ treatment at $580 \mathrm{ppm}\left(\mathrm{NICO}_{2}\right)$. All chambers were supplied with charcoal-filtered air. Treated germinated plants were fumigated with elevated $\mathrm{CO}_{2}$ and $\mathrm{O}_{3}$ until maturity from 11.00 to $15.00 \mathrm{~h}$. Plants remained under these conditions until the harvest stage. Elevated levels of $\mathrm{O}_{3}$ were generated by electric discharge, passing pure oxygen through a Welsbach Ozone Generator (USA), which contained a UV lamp causing oxygen to break down and the consequent formation of $\mathrm{O}_{3}$. Gas cylinders containing elevated levels of $\mathrm{CO}_{2}$ were obtained from Hibro Tech Development Co., Ltd (UK) and had regulated gas flow.

\section{Biochemical analysis of proteins using SDS-PAGE}

\section{Preparation of grain cake and defatted meal preparation}

Dried and sterilized grains of treated and untreated wheat plants were milled and defatted according to the method described by Hojilla-Evangelista and Evangelista (2006).

\section{Extraction of grain storage proteins and SDS-PAGE analysis}

The protein extraction technique used was similar to that employed by Saraswati et al. (1993). Sample buffer was added to $0.2 \mathrm{~g}$ grain flour and mixed thoroughly in an Eppendorf tube by vortexing. The extraction buffer contained the following: $0.5 \mathrm{M}$ Tris- $\mathrm{HCl}, \mathrm{pH} 6.8$, $2.5 \% \mathrm{SDS}, 5 \%$ urea, and 5\% 2-merkaptoethanol. Before centrifugation at 10,000 $\mathrm{g}$ for $5 \mathrm{~min}$ at $4^{\circ} \mathrm{C}$, the sample buffer was boiled for $5 \mathrm{~min}$. SDS-PAGE was performed by a standard method on a vertical slab gel. Bromophenol blue was added to the supernatant as a tracking dye to visualize the movement of protein on the gel. Proteins in samples were profiled using SDSpolyacrylamide gels as described by Laemmli (1970). Grain proteins were analyzed by SDSPAGE using $10 \%$ polyacrylamide gel. After electrophoresis, the protein bands were visualized 
by staining with Coomassie brilliant blue G-250. Marker proteins (Fermentas) were used as references. The polypeptide bands produced in the electropherogram were scored and their molecular weights were compared to the standard Pharmacia protein marker.

\section{Gel photographing and data analysis}

Gels were photographed and documented using the Bio-Rad gel documentation system. The bands on each gel lane were counted and compared using Gel Pro-Analyzer. Variations in band number as well as band density were estimated using Bio-Rad Video densitometer, Model Gel Doc 2000. To assess variation in the protein banding pattern, electropherograms of each germplasm of treated and untreated wheat plants were scored for the presence or absence of polypeptide bands.

\section{Biochemical analysis of isozymes}

\section{Isozyme extraction, polyacrylamide gel electrophoresis, and staining methods}

Six isozymes, malate dehydrogenase (MDH), amylase (AMY), leucineaminopeptidase (LAP), esterase (EST), peroxidase (PER), and catalase (CAT) were used in this experiment. Viable, cleaned, and sterilized grains of treated and non-treated wheat plants were separately milled and defatted according to the methods described by HojillaEvangelista and Evangelista (2006). Approximately 0.4 g powdered grains were crushed with acid-washed sand and $400 \mathrm{~mL}$ extraction buffer. Extraction buffer consisted of $0.1 \mathrm{M}$ Tris- $\mathrm{HCl}$ (pH 7.5) containing 20\% sucrose as described by Majumder et al. (2012). The samples were then centrifuged at $15,000 \mathrm{~g}$ for $15 \mathrm{~min}$ at $4{ }^{\circ} \mathrm{C}$; supernatants were collected and used directly for isozyme analysis in a separate vial. Each sample was applied to vertical polyacrylamide gel electrophoresis (4.5\% stacking, 9\% separating gel) using a mini gel apparatus in Tris-glycine ( $\mathrm{pH}$ 8.3) buffer. Enzymatic activity after electrophoresis was visualized by histochemical analysis of the gels. The gels were stained for MDH, AMY, LAP, EST, PER, and CAT isozymes separately using a specific substrate solution to stain for the activity of each isozyme as previously described (Ravindranath and Fridovich, 1975; Sadasivam and Manickam, 1992; Georg-Kraemer and Cavalli, 2003; Johnson et al., 2012; Majumder et al., 2012). Each gel was incubated in the relevant staining solution for a few minutes in the dark until clear bands appeared. The gels were fixed with $7 \%$ acetic acid solution for $30 \mathrm{~min}$; the gels were washed with distilled water and photographed using the Vilber Lourmat gel documentation system.

\section{Identification of zymograms, gel scoring, and data analyses}

Isozymatic data were scored based on the presence or absence of zymograms of a unique isozymatic pattern. Isozymatic banding patterns observed after isozyme electrophoresis were compared among $\mathrm{CO}_{2}$ and $\mathrm{O}_{3}$ treatments based on their relative front $\left(\mathrm{R}_{\mathrm{f}}\right)$ values on gel electrophoresis, their optical intensities, and zymogram number as described by Mouemar and Gasquez (1983). Zymograms were drawn to scale, and the $R_{f}$ value of each respective zymogram on schematic isozyme patterns was determined to allow precise comparisons among the various treatments. 


\section{Molecular analysis based on the RAPD-PCR technique}

\section{Isolation of genomic DNA}

Genomic DNA from dried grains of $\mathrm{CO}_{2}$ - and $\mathrm{O}_{3}$-treated wheat plants was extracted using the hexadecyl trimethyl ammonium bromide as described by Kit and Chandran (2010).

\section{Qualitative and quantitative analyses of extracted DNA}

The DNA yield was measured using a UV-visible spectrophotometer (PerkinElmer, Waltham, MA, USA) at $260 \mathrm{~nm}$. DNA purity was determined by calculating the absorbance ratio at $\mathrm{A}_{260 / 280} \mathrm{~nm}$. Polysaccharide contamination was assessed by calculating the absorbance ratio at $\mathrm{A}_{260 / 230} \mathrm{~nm}$ (Wilson and Walker, 2005). For quality and yield assessments, electrophoresis was performed for all of the DNA samples on $0.8 \%$ agarose gels, and the gels were stained with ethidium bromide. The bands were observed in a gel documentation system (AlphaInnotech, San Leandro, CA, USA) and compared with the known standard lambda DNA marker.

\section{PCR amplification using random primers of RAPD and agarose gel electrophoresis}

The PCR mixture contained $2.5 \mu \mathrm{L} 10 \mathrm{X}$ buffer with $15 \mathrm{mM} \mathrm{MgCl}_{2}$ (Fermentas, Vinius, Lithuania), with $0.25 \mathrm{mM}$ each dNTP (Sigma, St. Louis, MO, USA), $0.3 \mu \mathrm{M}$ primer, $0.5 \mathrm{U}$ Taq DNA polymerase (Sigma), and 50ng template DNA. PCR was performed in the Palm Cycler apparatus (Corbett Research) using the following profile: initial denaturation of $4 \mathrm{~min}$ at $95^{\circ} \mathrm{C}$ followed by 40 cycles of $1 \mathrm{~min}$ at $95^{\circ} \mathrm{C}, 1 \mathrm{~min}$ at $38^{\circ} \mathrm{C}$, and $2 \mathrm{~min}$ at $72^{\circ} \mathrm{C}$, with a final extension at $72^{\circ} \mathrm{C}$ for $10 \mathrm{~min}$ and a hold temperature of $4^{\circ} \mathrm{C}$ at the end. A total of 20 random DNA oligonucleotide primers (10 mer) were independently used in the PCR (University of British Columbia, Canada) according to the method described by Williams et al. (1990) with some modifications. Only seven primers (P-02, 03, 05, 08, 11, 15, and 17) successfully generated reproducible products. For DNA amplification, PCR was run for 35 cycles, which consisted of a denaturation step $\left(1 \mathrm{~min}\right.$ at $\left.95^{\circ} \mathrm{C}\right)$, an annealing step $\left(1 \mathrm{~min}\right.$ at $\left.35^{\circ} \mathrm{C}\right)$, and an elongation step $\left(2 \mathrm{~min}\right.$ at $\left.72^{\circ} \mathrm{C}\right)$. After 34 cycles, a final extension period was added $\left(5 \min\right.$ at $\left.72^{\circ} \mathrm{C}\right)$. The amplification products were electrophoresed on $1.5 \%$ agarose gel (Sigma) in TAE buffer $(0.04 \mathrm{M}$ Tris-acetate, $1 \mathrm{mM}$ EDTA, $\mathrm{pH}$ 8). The run was performed at 100-V constant voltage for $1 \mathrm{~h}$. Gels were stained with $0.2 \mathrm{mg} / \mathrm{mL}$ ethidium bromide for $15 \mathrm{~min}$. The PCR products were visualized under a UV light transilluminator. A 100-bp DNA ladder (Gibco-BRL, Grand Island, NY, USA) was loaded into the first lane of each gel to evaluate band sizes. The gels were photographed under UV light using a gel documentation system (Bio-Rad, Hercules, CA, USA).

\section{Agarose gel scoring and data analyses}

After separating PCR products by agarose gel electrophoresis, the gels were visualized using a Photo Print (Vilber Lourmat, France) imaging system. Quantitative variations in the number of amplified DNA bands, their size, and intensity were analyzed using the Bio-One $\mathrm{D}++$ software (Vilber Lourmat, France). Data were scored as the presence or absence of DNA bands. Polymorphic DNA bands (unique and non-unique) and monomorphic bands were also scored. Polymorphism in biomarker profiles included the loss of a normal band and the appearance of a new band, as compared with the control. 


\section{Molecular cytogenetic analysis based on the comet assay}

\section{Preparation of nuclei suspensions}

Nuclei were isolated as described by Sliwinska et al. (2009) by chopping wheat grains in a Petri dish containing $200 \mu \mathrm{L}$ cold $400 \mathrm{mM}$ Tris-HCl buffer, $\mathrm{pH} 7.5$ (kept on ice), using a fresh sharp scalpel to release nuclei into the buffer under yellow light. This method of isolating nuclei minimized DNA damage in the control cells. The resultant suspension of nuclei was used in the alkaline SCGE, as described by Juchimiuk et al. (2006). Each slide previously coated with $1 \%$ normal melting point agarose and dried, was covered with a mixture of $55 \mu \mathrm{L}$ nuclear suspension and $55 \mu \mathrm{L}$ low melting point (LMP) agarose (1\% prepared with phosphatebuffered saline) at $40^{\circ} \mathrm{C}$ and cover slipped. The slide was placed on ice for at least $5 \mathrm{~min}$, and the coverslip was removed. Then, $110 \mu \mathrm{L}$ LMP agarose $(0.5 \%)$ was placed on the slide and the coverslip was mounted. After 5 min on ice, the coverslip was removed. Slides of SCGE with wheat nuclei were prepared as described by Juchimiuk et al. (2006) and placed in a horizontal gel electrophoresis tank containing freshly prepared cold electrophoresis buffer $(300 \mathrm{mM}$ $\mathrm{NaOH}, 1 \mathrm{mM}$ EDTA, $\mathrm{pH}>13$ ) and incubated for $15 \mathrm{~min}$. Electrophoresis was performed at 16 $\mathrm{V}, 300 \mathrm{~mA}$, for $30 \mathrm{~min}$ at $4^{\circ} \mathrm{C}$. Next, the gels were neutralized by washing three times in 400 $\mathrm{mM}$ Tris- $\mathrm{HCl}, \mathrm{pH} 7.5$ and stained with ethidium bromide $(20 \mu \mathrm{g} / \mathrm{mL})$ for $5 \mathrm{~min}$. After staining, the gels were dipped in ice-cold distilled water and immediately analyzed.

\section{Imaging and analysis software}

DNA-lesions in 50 randomly selected nuclei on each slide were analyzed and assessed qualitatively and quantitatively by visual scoring or by using the fluorescence microscope with an excitation filter of $546 \mathrm{~nm}$, a barrier filter of $590 \mathrm{~nm}$, and a computerized CCD camera digital image analysis system (Komet Version 3.1. Kinetic Imaging, Liverpool, UK). Tail moment (TM, integrated value of DNA density multiplied by migration distance) became a common descriptor along with tail length $(\mu \mathrm{m})$ and percentage of DNA in the tail, tail DNA (TD\%, relative percentage of DNA in the comet tail), were used as parameters of DNA damage.

\section{RESULTS}

\section{Biochemical SDS-PAGE analysis}

Electrophoretic banding patterns, as revealed by SDS-PAGE, were used to detect and estimate changes in storage proteins in wheat grains induced by $\mathrm{ICO}_{2}, \mathrm{IO}_{3}, \mathrm{NICO}_{2}$, and $\mathrm{NIO}_{3}$ treatments, on their own and in combination as shown in Table 1 and Figure 1. The polypeptide banding patterns generated by SDS-PAGE varied between treated samples and the control group based on molecular weight $(\mathrm{kDa})$, band intensity, fractionation of bands, appearance of new bands (unique bands appearing in only one sample), and the loss of some bands (nonunique bands appeared in some samples and not others). The results revealed a total of 169 polypeptide bands with different molecular weights ranging from 24.0 to $300.0 \mathrm{kDa}$, of which 95 bands were polymorphic with a value of $56.21 \%$ (61 unique polypeptide bands with a value of $36.10 \%$, plus 34 non-unique bands with value of $20.11 \%$ ).

The polymorphism value generated by SDS-PAGE was $100 \%$ based on the absence 
of monomorphic bands (bands that appear in all samples). There were clear variations in molecular weight among different treatments. The maximum number of polypeptides bands was 25 , with a value $14.79 \%$ for the $\mathrm{NICO}_{2}$ treatment while the minimum number was 20 , with a value $11.83 \%$ for the NI $\left(\mathrm{CO}_{2}+\mathrm{O}_{3}\right)$ treatment compared to the non-irrigated (18 polypeptides bands; $10.65 \%$ ).

SDS-PAGE generated a total of 61 unique polypeptide bands, which varied in number, molecular weight $(\mathrm{kDa})$, and band intensity among treated and untreated samples (Table 1). Therefore, these bands can be used as biomarkers for the appearance new characteristic polypeptide bands that are specific for each treatment. The maximum number of unique polypeptides bands was 16 , with a value of $26.23 \%$ for samples subjected to the $\mathrm{ICO}_{2}$ treatment compared to four unique bands, with a value of $6.56 \%$ in ICF. The minimum number of unique polypeptides bands was 2 , with a value of $3.28 \%$ for the $\mathrm{NI}\left(\mathrm{CO}_{2}+\mathrm{O}_{3}\right)$ treatment compared to 5 unique bands, with a value of $8.20 \%$, for the NICF (Table 1).

Table 1. SDS-PAGE analysis of storage proteins in wheat grains untreated and treated with $\mathrm{CO}_{2}$ and $\mathrm{O}_{3}$ with and without irrigation.

\begin{tabular}{|c|c|c|c|c|c|c|c|c|c|c|c|c|c|c|c|}
\hline \multirow[t]{3}{*}{$\begin{array}{l}\text { Treatments } \\
\text { Thents }\end{array}$} & \multicolumn{5}{|c|}{ Polypeptide bands } & \multicolumn{3}{|r|}{ Unique polypeptide bands (U) } & \multicolumn{6}{|c|}{ Types and frequency of Polymorphic bands } & \multirow[t]{3}{*}{ Polymorphism (\%) } \\
\hline & \multirow[t]{2}{*}{$\mathrm{N}$} & \multirow[t]{2}{*}{ Total } & \multirow[t]{2}{*}{$\%$} & \multirow[t]{2}{*}{ Molecular weight (kDa) } & \multirow[t]{2}{*}{ Optical intensity $(\%)$} & \multirow[t]{2}{*}{$\mathrm{N}$} & \multirow[t]{2}{*}{$\%$} & \multirow[t]{2}{*}{ Molecular weights (kDa) } & \multirow{2}{*}{\multicolumn{2}{|c|}{ Unique }} & \multicolumn{2}{|c|}{ Non- $\mathrm{U}$} & \multicolumn{2}{|c|}{ Total } & \\
\hline & & & & & & & & & & & $\mathrm{N}$ & $\%$ & $\mathrm{~N}$ & $\%$ & \\
\hline $\mathrm{ICO}_{2}$ & 23 & 169 & 13.61 & $280.2-36.0$ & $9.8-1.3$ & 16 & 26.23 & 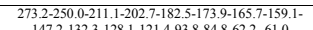 & 61 & 36.10 & 34 & 20.11 & 95 & 56.21 & 100 \\
\hline $\mathrm{IO}_{3}$ & 21 & & 12.43 & $279.9-56.0$ & $9.9-1.8$ & 8 & 13.12 & 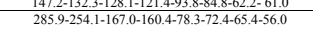 & & & & & & & \\
\hline $\mathrm{I}\left(\mathrm{CO}_{2+} \mathrm{O}_{3}\right)$ & 22 & & 13.02 & $260.3-36.0$ & $10.7-1.4$ & 4 & 6.56 & $260.3-78.9-73.4-57.0$ & & & & & & & \\
\hline ICF & 19 & & 11.24 & $271.0-60.5$ & $34.0-1.1$ & 4 & 6.56 & $271.0-246.0-115.7-69.3$ & & & & & & & \\
\hline NICF & 18 & & 10.65 & $266.7-60.5$ & $27.0-1.11$ & 5 & 8.20 & $144.9-133.7-122.7-67.8-63.9$ & & & & & & & \\
\hline $\mathrm{NI}\left(\mathrm{CO}_{24} \mathrm{O}_{3}\right)$ & 21 & & 12.43 & $289.1-60.5$ & $23.3-1.0$ & 2 & 3.28 & $283.2-262.4$ & & & & & & & \\
\hline $\mathrm{NIO}_{3}$ & 20 & & 11.83 & $266.7-61.1$ & $17.9-1.1$ & 11 & 16.39 & $300.0-289.1-268.8-234.4-144.1-87.3-77.2-69.8-64.9-$ & & & & & & & \\
\hline $\mathrm{NICO}_{2}$ & 25 & & 14.79 & $300.0-24.0$ & $31.3-1.9$ & 12 & 19.67 & 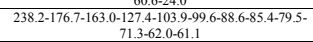 & & & & & & & \\
\hline
\end{tabular}

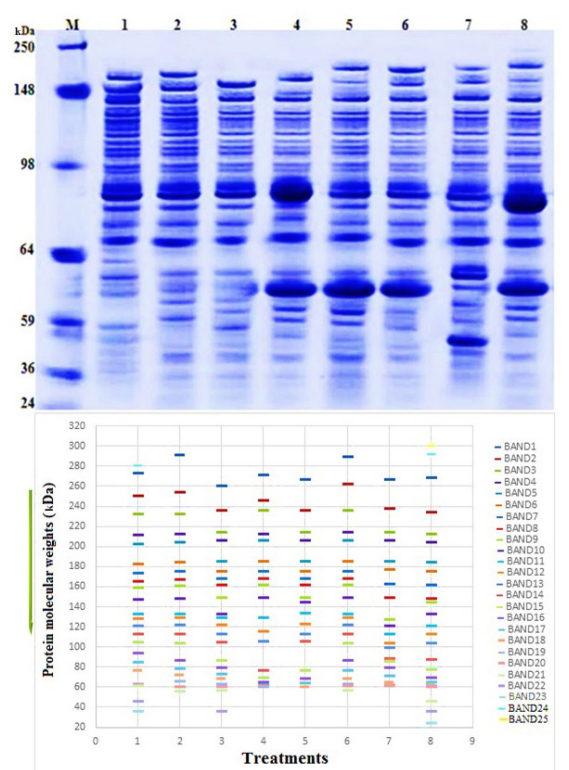

Figure 1. Protein banding pattern (upper) and schematic distribution (lower) of polypeptide bands generated by sodium dodecyl sulfate-polyacrylamide gel electrophoresis (SDS-PAGE) in wheat grains untreated and treated with $\mathrm{CO}_{2}$ and $\mathrm{O}_{3}$ with and without irrigation. Lanes 1-8 $=\mathrm{ICO}_{2}, \mathrm{IO}_{3}, \mathrm{I}\left(\mathrm{CO}_{2}+\mathrm{O}_{3}\right)$, ICF, NICF, NI $\left(\mathrm{CO}_{2}+\mathrm{O}_{3}\right), \mathrm{NIO}_{3}$, and $\mathrm{NICO}_{2}$ treatments, respectively. 


\section{Biochemical isozyme analysis}

MDH, AMY, LAP, EST, PER, and CAT isozymes showed 100\% polymorphism values between untreated and treated wheat grains based on zymogram number, loci, $R_{f}$ values, and optical intensities (Tables 2 and 3 and Figures 2 and 3). A total of 219 different electrophoretic zymograms generated by the six isozymes had varied $\mathrm{R}_{\mathrm{f}}$ values, ranging from 0.03 to 1.10 , of which 139 zymograms, with a value of $63.47 \%$ were polymorphic $(88$ unique zymograms with a value of $40.18 \%$ plus 51 non- unique zymograms with a value of 23.29\%). Analyses of MDH, AMY, LAP, EST, PER, and CAT generated 24, 24, 45, 25, 58 , and 43 zymograms, respectively, with different $R_{f}$ values. The maximum number of zymograms generated by six isozymes was 30 ; with a value of $13.70 \%$ for samples subjected to the NI $\left(\mathrm{CO}_{2}+\mathrm{O}_{3}\right)$ treatment compared to 28 zymograms, with a value $12.79 \%$ for NI samples. Conversely, the minimum number of zymograms was 24 , with a value $10.96 \%$ for samples subjected to I $\left(\mathrm{CO}_{2}+\mathrm{O}_{3}\right)$ compared to 29 zymograms, with a value of $13.24 \%$ for control samples subjected to irrigation.

Unique zymograms (new characteristic loci appearing in samples from one treatment group only) varied in $R_{f}$ values and optical intensities. The maximum number of unique zymograms generated by six isozymes was 16 ; with a value of $18.18 \%$ scored for samples subjected to $\mathrm{NICO}_{2}$ treatment, compared to four unique zymograms; with a value of $4.55 \%$ in NI untreated samples. Conversely, $\mathrm{I}\left(\mathrm{CO}_{2}+\mathrm{O}_{3}\right)$ samples had the maximum number of unique zymograms (15 zymograms), with a value of $17.05 \%$ as against irrigated untreated samples, which scored nine zymograms; with a value of $10.23 \%$ (Table 3 ).

Table 2. Zymograms produced by malate dehydrogenase (MDH), amylase (AMY), leucine-aminopeptidase (LAP), esterase (EST), peroxidase (PER), and catalase (CAT) isozymes extracted from untreated and treated wheat grains with $\mathrm{CO}_{2}$ and $\mathrm{O}_{3}$ with and without irrigation.

\begin{tabular}{|c|c|c|c|c|c|c|c|c|c|c|c|c|c|c|c|c|c|c|}
\hline \multirow[t]{3}{*}{ Isozymes } & \multirow[t]{3}{*}{ Rf values } & \multicolumn{10}{|c|}{ Total number of zymograms } & \multicolumn{6}{|c|}{ Type and frequency of zymograms } & \multirow[t]{3}{*}{ Polymorphisms (\% } \\
\hline & & Lane 1 & Lane 2 & Lane 3 & Lane 4 & Lane 5 & Lane 6 & Lane 7 & Lane 8 & \multicolumn{2}{|c|}{ Total } & \multicolumn{2}{|c|}{ Unique (U) } & \multicolumn{2}{|c|}{ Non-U } & \multicolumn{2}{|c|}{ Polymorphic } & \\
\hline & & $\mathrm{ICO}_{2}$ & $\mathrm{IO}_{3}$ & $\mathrm{I}\left(\mathrm{CO}_{2}+\mathrm{O}_{3}\right)$ & ICF & NICF & $\mathrm{NI}\left(\mathrm{CO}_{2}+\mathrm{O}_{3}\right)$ & $\mathrm{NIO}_{3}$ & $\mathrm{NICO}_{2}$ & $\mathrm{~N}$ & $\%$ & $\mathrm{~N}$ & $\%$ & $\mathrm{~N}$ & $\%$ & $\mathrm{~N}$ & $\%$ & \\
\hline MDH & $0.07-0.89$ & 3 & 3 & 3 & 3 & 3 & 3 & 3 & 3 & 24 & 10.96 & 13 & 54.17 & 5 & 20.83 & 18 & 75.00 & 100 \\
\hline AMY & $0.15-0.91$ & 3 & 3 & 3 & 3 & 3 & 3 & 3 & 3 & 24 & 10.96 & 11 & 45.83 & 6 & 25.00 & 17 & 70.83 & 100 \\
\hline LAP & $0.03-1.6$ & 5 & 8 & 5 & 7 & 5 & 5 & 5 & 5 & 45 & 20.55 & 24 & 53.34 & 6 & 13.33 & 30 & 66.67 & 100 \\
\hline EST & $0.05-0.93$ & 3 & 3 & 3 & 3 & 3 & 3 & 3 & 4 & 25 & 11.42 & 25 & 100.00 & 0 & 00.00 & 25 & 100.00 & 100 \\
\hline PER & $0.08-1.10$ & 8 & 6 & 7 & 9 & 7 & 7 & 6 & 8 & 58 & 26.48 & 10 & 17.24 & 20 & 34.48 & 30 & 51.72 & 100 \\
\hline CAT & $0.11-0.90$ & 7 & 3 & 3 & 4 & 7 & 9 & 6 & 4 & 43 & 1964 & 5 & 11.63 & 14 & 3256 & 19 & 44,19 & 100 \\
\hline \multicolumn{2}{|c|}{$\frac{1}{\text { Overall total }}$} & 29 & 26 & 24 & 29 & 28 & 30 & 26 & 27 & & $\frac{11907}{219}$ & 88 & 40.18 & 51 & 23.29 & 139 & 63.47 & 100 \\
\hline \multicolumn{2}{|c|}{$\%$} & 13.24 & 11.87 & 10.96 & 13.24 & 12.79 & 13.70 & 11.87 & 12.33 & & & & & & & & & \\
\hline
\end{tabular}

\begin{tabular}{|c|c|c|c|c|c|c|c|c|c|c|c|c|c|c|c|c|}
\hline \multirow[t]{4}{*}{ Isozymes } & \multicolumn{16}{|c|}{ Number and $R_{f}$ values of unique zymograms } \\
\hline & \multirow{2}{*}{\multicolumn{2}{|c|}{$\begin{array}{l}\text { Lane } 1 \\
\mathrm{ICO}_{2}\end{array}$}} & \multirow{2}{*}{\multicolumn{2}{|c|}{$\begin{array}{c}\text { Lane } 2 \\
\mathrm{IO}_{3}\end{array}$}} & \multirow{2}{*}{\multicolumn{2}{|c|}{$\begin{array}{c}\text { Lane } 3 \\
\mathrm{I}\left(\mathrm{CO}_{2}+\mathrm{O}_{3}\right)\end{array}$}} & \multirow{2}{*}{\multicolumn{2}{|c|}{$\frac{\mathrm{Lane} 4}{\mathrm{ICF}}$}} & \multirow{2}{*}{\multicolumn{2}{|c|}{$\frac{\text { Lane } 3}{\text { NICF }}$}} & \multirow{2}{*}{\multicolumn{2}{|c|}{$\begin{array}{c}\text { Lane } 6 \\
\mathrm{NI}\left(\mathrm{CO}_{2}+\mathrm{O}_{3}\right)\end{array}$}} & \multirow{2}{*}{\multicolumn{2}{|c|}{$\begin{array}{l}\text { Lane } 7 \\
\mathrm{NIO}_{3}\end{array}$}} & \multicolumn{2}{|r|}{ Lane 8} \\
\hline & & & & & & & & & & & & & & & & $\mathrm{NICO}_{2}$ \\
\hline & $\mathrm{N}$ & $\mathrm{R}_{\mathrm{f}}$ & $\mathrm{N}$ & $\mathrm{Rf}_{\mathrm{f}}$ & $\mathrm{N}$ & $\mathrm{Rf}$ & $\mathrm{N}$ & $\mathrm{Rf}$ & $\mathrm{N}$ & $\mathrm{Rf}_{\mathrm{f}}$ & $\mathrm{N}$ & $\mathrm{R}_{f}$ & $\mathrm{~N}$ & $\mathrm{Rf}_{\mathrm{f}}$ & $\mathrm{N}$ & $\mathrm{Rf}$ \\
\hline MDH & 2 & $0.26-0.68$ & 1 & 0.710 & 2 & $0.15-0.82$ & 2 & $0.16-0.43$ & 0 & - & 2 & $0.08-0.64$ & 2 & $0.50-0.89$ & 2 & $0.13-0.84$ \\
\hline AMY & 0 & - & 1 & 0.430 & 3 & $0.20-0.46-0.88$ & 1 & 0.16 & 1 & 0.18 & 2 & $0.19-0.89$ & 1 & 0.91 & 2 & $0.49-0.90$ \\
\hline LAP & 3 & $0.29-0.36-0.55$ & 5 & $\begin{array}{c}0.15-0.25-0.30- \\
0.38-1.05\end{array}$ & 6 & $\begin{array}{c}0.14-0.43-0.50- \\
0.68-0.86-0.93\end{array}$ & 1 & 0.05 & 0 & - & 0 & - & 4 & $\begin{array}{l}0.32-0.40- \\
0.58-0.80\end{array}$ & 5 & $\begin{array}{c}0.16-0.45-0.52- \\
0.66-0.95\end{array}$ \\
\hline EST & 3 & $0.15-0.57-0.85$ & 3 & $0.053-0.230-0.690$ & 3 & $0.09-0.51-0.92$ & 3 & $0.05-0.22-0.67$ & 3 & $0.08-0.68-0.86$ & 3 & $\begin{array}{c}0.07- \\
0.25-0.70 \\
\end{array}$ & 3 & $\begin{array}{c}0.08-0.38- \\
0.84\end{array}$ & 4 & $\begin{array}{c}0.06-0.28-0.50- \\
0.93\end{array}$ \\
\hline PER & 2 & $0.99-1.06$ & 3 & $0.46-0.66-0.76$ & 1 & 0.61 & 2 & $0.13-0.74$ & 0 & - & 0 & - & 1 & 0.86 & 1 & 0.11 \\
\hline CAT & 2 & $0.44-0.71$ & 1 & 0.78 & 0 & - & 0 & - & 0 & - & 0 & - & 0 & - & 2 & $0.18-0.50$ \\
\hline Total & & 12 & & 14 & & 15 & & 9 & & 4 & & 7 & & 11 & & 16 \\
\hline Sum & & & & & & & & 88 & & & & & & & & \\
\hline$\%$ & & 13.64 & & 15.91 & & 17.05 & & 10.23 & & 4.55 & & 7.95 & & 12.5 & & 18.18 \\
\hline
\end{tabular}




\section{Molecular DNA-based RAPD-PCR analysis}

RAPD analysis was employed in the current study to evaluate the extent of DNA damage in untreated and treated wheat plant as shown in Tables 4 and 5 and in Figure 4. Of the 20 random decamer primers tested, only seven 10-bp random RAPD primers with $60-70 \%$ GC content gave specific and consistent bands and succeeded in revealing distinctive changes in the amplified DNA banding pattern. RAPD analysis revealed a total of 276 reproducible and clear amplified DNA bands with different lengths, ranging from 45 to $1100 \mathrm{bp}$ in untreated and treated samples. Of these, 120 amplified DNA bands, with a value of $43.48 \%$, were polymorphic (91 unique DNA bands with a value of $32.97 \%$; 29 non-unique bands with a value of $10.51 \%$; 10 monomorphic DNA bands with a value of 3.62\%). Monomorphic DNA bands appeared at the same loci with the same molecular size in all treatments, and in the control, although they differed in intensity.

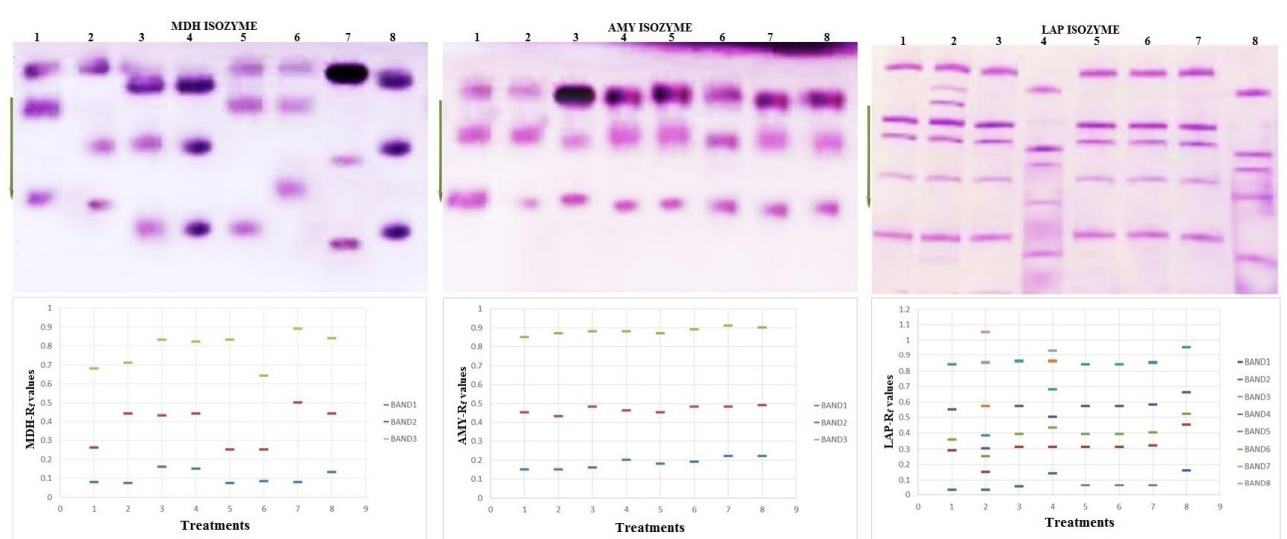

Figure 2. Isozymatic banding pattern (upper) and schematic distribution (lower) of zymograms $\mathrm{R}_{\mathrm{f}}$ values generated by MDH, AMY, and LAP isozymes. Lanes 1-8 $=\mathrm{ICO}_{2}, \mathrm{IO}_{3}, \mathrm{I}\left(\mathrm{CO}_{2}+\mathrm{O}_{3}\right)$, ICF, NICF, NI $\left(\mathrm{CO}_{2}+\mathrm{O}_{3}\right), \mathrm{NIO}_{3}$, and $\mathrm{NICO}_{2}$ treatments, respectively.

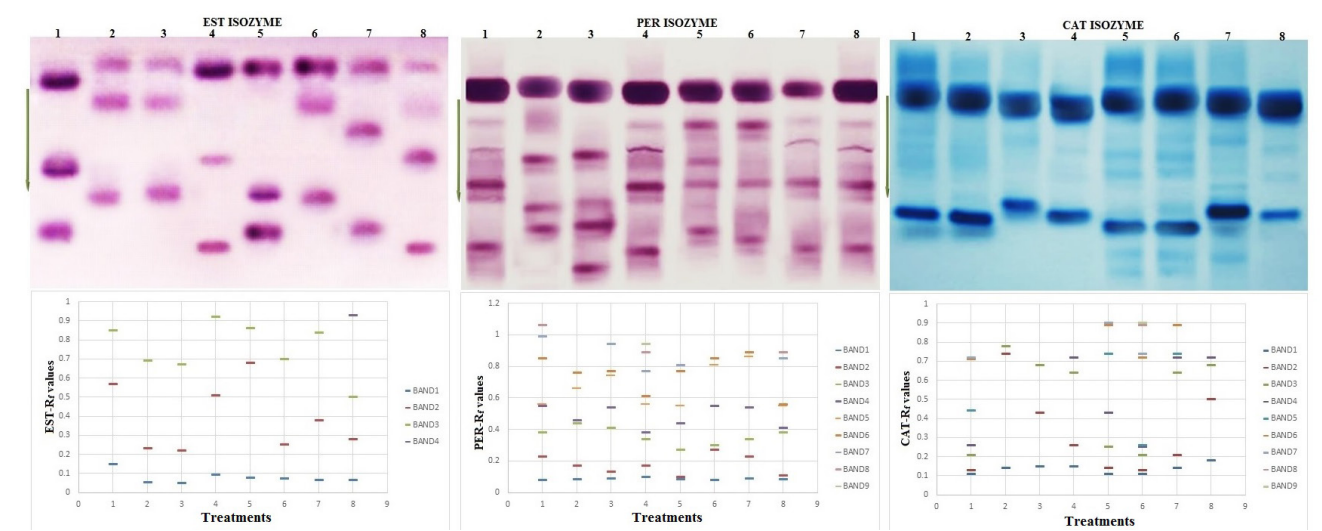

Figure 3. Isozymatic banding pattern (upper) and schematic distribution (lower) of zymograms $\mathrm{R}_{\mathrm{f}}$ values generated by EST, PER, and CAT isozymes. Lanes 1-8 $=\mathrm{ICO}_{2}, \mathrm{IO}_{3}, \mathrm{I}\left(\mathrm{CO}_{2}+\mathrm{O}_{3}\right)$, ICF, NICF, $\mathrm{NI}\left(\mathrm{CO}_{2}+\mathrm{O}_{3}\right), \mathrm{NIO}_{3}$, and $\mathrm{NICO}_{2}$ treatments, respectively. 
An average of 39.43 bands per primer was scored. RAPD analysis generated polymorphism values of $92.31 \%$, which presented as the loss and/or appearance of DNA fragments in treated samples compared to the control. Primer-11 produced the maximum number of amplified DNA bands at 53, with a value of $19.20 \%$, while primer- 08 produced the minimum number of amplified DNA bands at 27, with a value of $9.78 \%$. Conversely, the maximum number of amplified DNA bands was 47 , with a value of $17.03 \%$, which was generated by seven primers and was observed in samples subjected to $\mathrm{ICO}_{2}$ treatment. This compared to 32 bands, with a value $11.59 \%$ for the control, while the minimum number of amplified DNA bands was 30 , with a value of $10.87 \%$ in samples subjected to $\mathrm{IO}_{3}$ treatment. Unique amplified DNA bands were characteristic loci specific for one treatment based on the number of DNA bands, their molecular sizes, and optical intensities. The maximum number of unique DNA bands generated by seven primers was 27 , with a value of $29.67 \%$ scored in samples subjected to $\mathrm{ICO}_{2}$ treatment, compared to 10 unique bands, which had a value of $10.99 \%$ scored in the irrigated untreated sample, while the minimum number of unique DNA bands was eight, with a value of $8.79 \%$ for the irrigated elevated $\left(\mathrm{CO}_{2}+\mathrm{O}_{3}\right)$ treatment (Table 5).

Table 4. RAPD products of DNA extracted from grains of untreated and treated wheat plants with irrigated and non-irrigated $\mathrm{CO}_{2}$ and $\mathrm{O}_{3}$ treatments using seven random primers. Lanes 1-8 represent $\mathrm{ICO}_{2}, \mathrm{IO}_{3}, \mathrm{I}\left(\mathrm{CO}_{2}+\mathrm{O}_{3}\right)$, ICF, NICF, $\mathrm{NI}\left(\mathrm{CO}_{2}+\mathrm{O}_{3}\right), \mathrm{NIO}_{3}$, and $\mathrm{NICO}_{2}$ treatments, respectively.

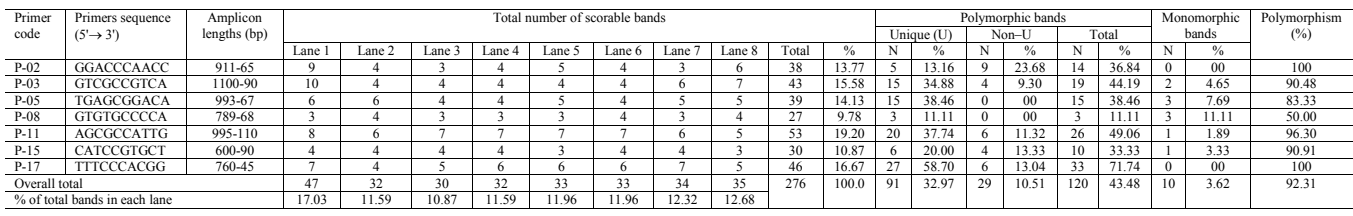

Table 5. Number, size (bp), and frequency of unique DNA bands produced by seven random primers in untreated and treated wheat plant with $\mathrm{CO}_{2}$ and $\mathrm{O}_{3}$ with and without irrigation.

\begin{tabular}{|c|c|c|c|c|c|c|c|c|c|c|c|c|c|c|c|c|}
\hline \multirow[t]{4}{*}{ Primers } & \multicolumn{16}{|c|}{ Number, sizes (bp) and frequency of unique DNA bands } \\
\hline & \multirow{2}{*}{\multicolumn{2}{|c|}{$\begin{array}{ll}\text { Lane } 1 \\
\mathrm{ICO}_{2} \\
\end{array}$}} & \multirow{2}{*}{\multicolumn{2}{|c|}{$\begin{array}{l}\text { Lane } 2 \\
\mathrm{IO}_{3}\end{array}$}} & \multirow{2}{*}{\multicolumn{2}{|c|}{$\begin{array}{c}\text { Lane } 3 \\
\mathrm{I}\left(\mathrm{CO}_{2}+\mathrm{O}_{3}\right)\end{array}$}} & \multirow{2}{*}{\multicolumn{2}{|c|}{\begin{tabular}{|c|} 
Lane 4 \\
ICF \\
\end{tabular}}} & \multirow{2}{*}{\multicolumn{2}{|c|}{$\begin{array}{l}\text { Lane } 5 \\
\text { NICF }\end{array}$}} & \multirow{2}{*}{\multicolumn{2}{|c|}{$\begin{array}{c}\text { Lane } 6 \\
\mathrm{NI}\left(\mathrm{CO}_{2}+\mathrm{O}_{3}\right)\end{array}$}} & \multirow{2}{*}{\multicolumn{2}{|c|}{$\begin{array}{l}\text { Lane } 7 \\
\mathrm{NIO}_{3}\end{array}$}} & \multirow{2}{*}{\multicolumn{2}{|c|}{$\begin{array}{l}\text { Lane } 8 \\
\mathrm{NICO}_{2}\end{array}$}} \\
\hline & & & & & & & & & & & & & & & & \\
\hline & $\mathrm{N}$ & Size & $\mathrm{N}$ & Size & $\mathrm{N}$ & Size & $\mathrm{N}$ & Size & $\mathrm{N}$ & Size & $\mathrm{N}$ & Size & $\mathrm{N}$ & Size & $\mathrm{N}$ & Size \\
\hline P-02 & 4 & $792-690-320-285$ & 0 & - & 1 & 880 & 0 & - & 0 & - & 0 & - & 0 & - & 0 & \\
\hline P-03 & 8 & $\begin{array}{c}1100-988-975-750-680- \\
580-315-280\end{array}$ & 0 & - & 0 & & 1 & 550 & 0 & - & 1 & 700 & 2 & $520-192$ & 3 & $710-320-90$ \\
\hline P-05 & 3 & $993-988-550$ & 3 & $800-750-600$ & 1 & 530 & 1 & 500 & 2 & $488-67$ & 1 & 85 & 2 & $520-89$ & 2 & $830-98$ \\
\hline P-08 & 0 & & 1 & 588 & 0 & & 0 & & 0 & & 1 & 68 & 0 & - & 1 & 600 \\
\hline P-11 & 5 & $750-740-680-540-110$ & 2 & $800-588$ & 2 & $995-860$ & 4 & $950-830-640-590$ & 3 & $930-690-610$ & 2 & $890-780$ & 1 & 720 & 1 & 620 \\
\hline P-15 & 1 & 590 & 1 & 585 & 1 & 60 & 1 & 600 & 0 & - & 1 & 85 & 1 & 90 & 0 & \\
\hline P-17 & 6 & $640-443-330-216-110-45$ & 2 & $735-221$ & 3 & $417-271-85$ & 3 & $760-450-324$ & 3 & $400-199-65$ & 3 & $620-278-70$ & 4 & $560-380-200-80$ & 3 & $550-333-99$ \\
\hline Total & & 27 & & 9 & & 8 & & 10 & & 8 & & 9 & & 10 & & 10 \\
\hline Sum & & & & & & & & 91 & & & & & & & & \\
\hline$\%$ & & 29.67 & & 9.89 & & 8.79 & & 10.99 & & 8.79 & & 9.89 & & 10.99 & & 10.99 \\
\hline
\end{tabular}

\section{Molecular cytogenetic analysis based on comet assay}

In the present study, the comet assay was used to evaluate the extent of DNA damage in wheat nuclei in response to $\mathrm{CO}_{2}$ and $\mathrm{O}_{3}$ treatment, on their own and in combination under irrigated and non-irrigated conditions (Table 6 and Figure 5). In the comet assay, DNA with breaks migrates in the electric field towards the anode, resulting in a characteristic comet profile. The DNA migrating from the isolated nuclei, in addition to the higher percentage of TD \% and TM (fraction of migrated DNA multiplied by some measures of tail length) were 
used as parameters of DNA damage. The results showed there were distinctive variations in the extent of DNA damage in wheat nuclei. The highest DNA migration based on DNA damage parameters was as follows; tailed ratio $(30 \%)$, tail length $(8.70 \mu \mathrm{m}), \mathrm{TD} \%(8.01)$, and TM (34.18) observed for the $\mathrm{NIO}_{3}$ treatment compared to the non-irrigated untreated sample, which recorded tailed ratio (8\%), tail length $(3.11 \mu \mathrm{m}), \mathrm{TD} \%(2.45)$, and $\mathrm{TM}(7.62)$. The lowest DNA migration, tailed ratio (10\%), tail length $(3.74 \mu \mathrm{m})$, TD\% (2.46), and TM (9.20) were observed in response to the $\mathrm{ICO}_{2}$ treatment compared to the irrigated untreated sample, which recorded tailed ratio (4\%), tail length $(1.43 \mu \mathrm{m})$, TD (1.53\%), and TM (3.83) (Table 6).

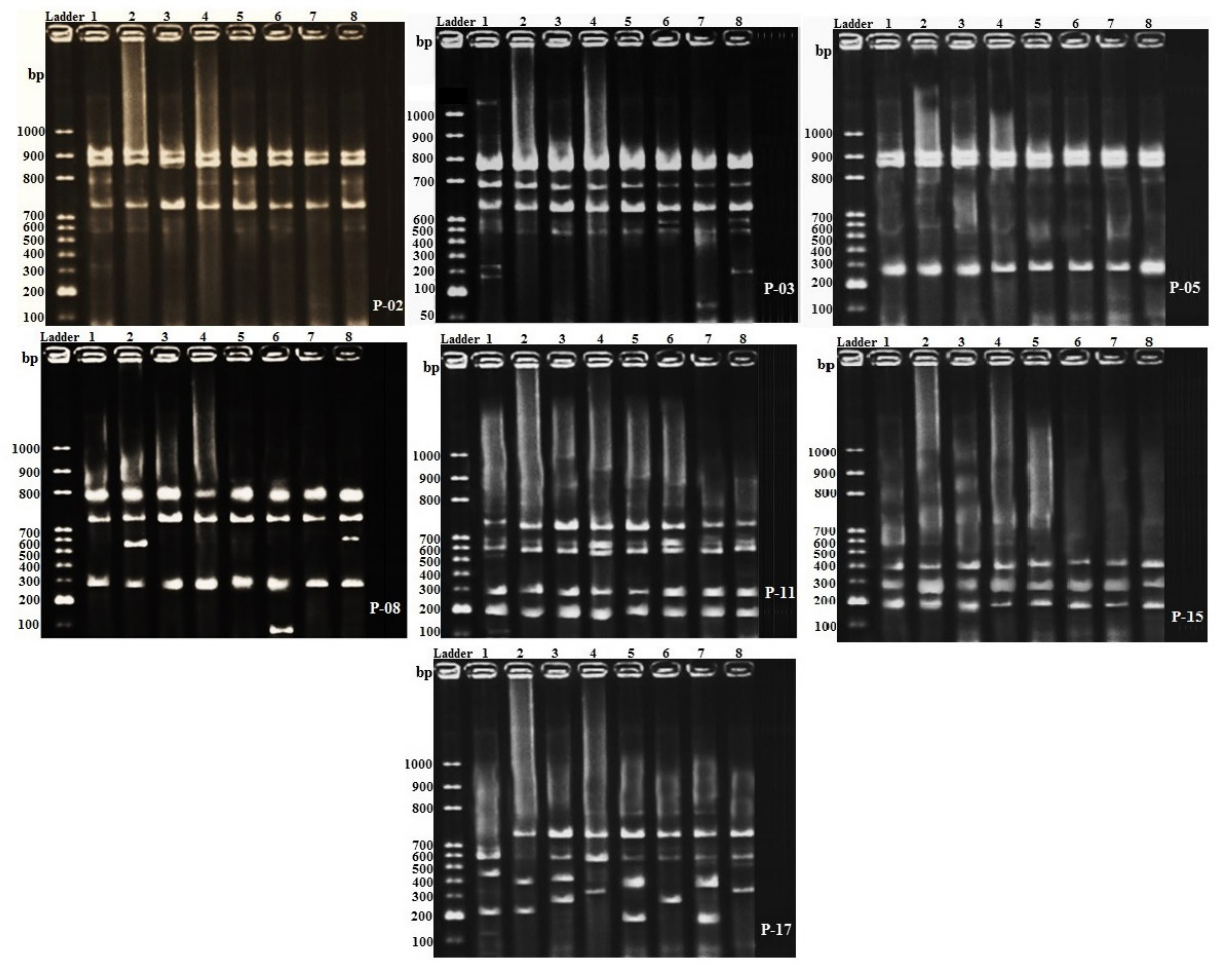

Figure 4. Random amplified polymorphic DNA (RAPD) profiles of genomic DNA generated by seven random decamer primers in wheat grains untreated and treated with $\mathrm{CO}_{2}$ and $\mathrm{O}_{3}$ with and without irrigation. Lanes 1-8 = $\mathrm{ICO}_{2}, \mathrm{IO}_{3}, \mathrm{I}\left(\mathrm{CO}_{2}+\mathrm{O}_{3}\right)$, ICF, NICF, $\mathrm{NI}\left(\mathrm{CO}_{2}+\mathrm{O}_{3}\right), \mathrm{NIO}_{3}$, and $\mathrm{NICO}_{2}$ treatments, respectively.

Table 6. Extent of nuclear DNA damage generated by single-cell gel electrophoresis (SCGE) in untreated and treated wheat nuclei with $\mathrm{CO}_{2}$ and $\mathrm{O}_{3}$ with and without irrigation.

\begin{tabular}{l|c|c|c|c|c}
\hline Treatment & Tailed $\%$ & Un-tailed \% & Tail length $(\mu \mathrm{m})$ & Tail DNA \% & Tail moment unit \\
\hline $\mathrm{ICO}_{2}$ & 10 & 90 & 3.74 & 2.46 & 9.20 \\
\hline $\mathrm{IO}_{3}$ & 20 & 80 & 5.80 & 5.34 & 22.61 \\
\hline $\mathrm{I}\left(\mathrm{CO}_{2}+\mathrm{O}_{3}\right)$ & 13 & 87 & 4.86 & 3.22 & 11.55 \\
\hline $\mathrm{ICF}$ & 4 & 96 & 1.43 & 3.53 & 3.83 \\
\hline $\mathrm{NICF}$ & 8 & 92 & 3.11 & 2.45 & 7.62 \\
\hline $\mathrm{NI}\left(\mathrm{CO}_{2}+\mathrm{O}_{3}\right)$ & 15 & 85 & 3.59 & 3.72 & 13.08 \\
\hline $\mathrm{NIO}_{3}$ & 30 & 70 & 8.70 & 8.01 & 3.18 \\
\hline $\mathrm{NICO}_{2}$ & 13 & 87 & 3.77 & 3.47 & 12.64 \\
\hline
\end{tabular}



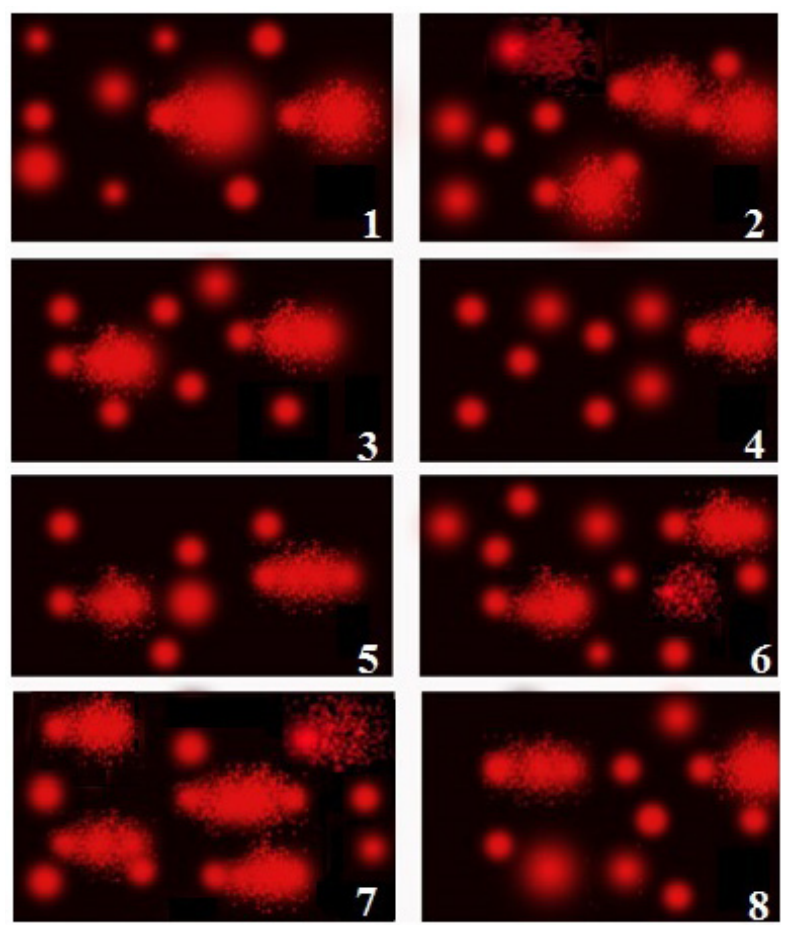

Figure 5. Comet images prepared by single cell gel electrophoresis (SCGE) show the variable extent of nuclear DNA damage of ELF $\mathrm{CO}_{2}$ and $\mathrm{O}_{3}$ treated and untreated wheat nuclei. The images 1-8 represent $\mathrm{ICO}_{2}, \mathrm{IO}_{3}, \mathrm{I}_{\left(\mathrm{CO}_{2}\right.}$ $\left.+\mathrm{O}_{3}\right)$, ICF, NICF, NI $\left(\mathrm{CO}_{2}+\mathrm{O}_{3}\right), \mathrm{NIO}_{3}$, and $\mathrm{NICO}_{2}$ treatments, respectivel.

\section{DISCUSSIONS}

The electrophoretic banding pattern of proteins observed in the current study provides information concerning the regulatory systems of structural genes that control the biosynthetic pathways of proteins in response to genotoxic environmental stress (Abdelhaliem et al., 2013; Al-Huqail and Abdelhaliem, 2015). Studies using SDS-PAGE analysis have shown that qualitative and quantitative changes in electrophoretic protein banding patterns occur in wheat grains exposed to $\mathrm{CO}_{2}$ and $\mathrm{O}_{3}$, on their own or in combination, compared to control samples under irrigated and non-irrigated conditions. These changes reflect the appearance of new polypeptide bands (unique bands) and the loss of normal polypeptide bands (non-unique bands) that varied in number, molecular weights, and band intensity, leading to high levels of protein polymorphisms. The bands produced in the polypeptide banding profile represent the end products of transcriptional and translational events occurring due to the activity of structural genes. Alterations in the banding pattern of electrophoretic proteins represent transcriptional events occurring due to the expression of genes under stress caused by different treatments, or due to mutations. The high levels of protein polymorphisms observed by SDS-PAGE may result from the addition, insertion, or deletion of amino acids between mutated sites of protein bands, or may result from changes in the amino acid sequences of proteins (Galani et al., 
2011). Conversely, variation in the number of polypeptide bands observed in treated samples compared to the control may result from changes in nitrogenous bases of DNA, in protein sites or amino acid sequences or frameshift mutations (Mondini et al., 2009). Interestingly, the number of different polypeptide bands arising from protein synthesis (alternative splicing and/or post-transcription modification) is significantly greater than the number of genes in a genome, thus it can be considered as markers of these genes (Mondini et al., 2009).

The appearance of new polypeptide bands (unique bands) observed in response to $\mathrm{CO}_{2}$ and $\mathrm{O}_{3}$ treatment may be explained by mutational events in unexpected genes or by the sub-fractionation of polypeptide bands due to gene duplication followed by a point mutation that encodes the fractionated band. In addition, this could also arise from numerous structural changes in the DNA such as additions, transpositions, or deletions, leading to changes in the amino acid sequence and the subsequent protein formed (Shikazono et al., 2005). Conversely, the loss of protein bands (non-unique) observed in response to some treatments indicates that $\mathrm{CO}_{2}$ and $\mathrm{O}_{3}$ have multiple effects on proteins. The loss of bands may be due to the breaking of a small number of peptide bonds, resulting in the formation of shorter polypeptide chains than possessed by the original protein, due to the loss of genetic material or deletion of the corresponding genes, or due to the aggregation or cross linking of individual polypeptide chains resulting in protein denaturation (Shikazono et al., 2005).

Changes in the relative mobility of polypeptide bands based on different molecular weights could be explained by the presence of point mutations in the related structural genes, which create stop codons before or after the original protein that lead to the production of longer or shorter polypeptide chains (Mondini et al., 2009). Changes in the intensity of polypeptide bands may result from changes in the expression of regulatory genes or from gene mutations in the regulatory system, which modulate or increase the rate of transcription of a particular structural gene, as suggested by Abdelhaliem et al. (2013) and Al-Huqail and Abdelhaliem (2015). The alterations observed in protein banding pattern induced by variable levels of oxidative stress produced by $\mathrm{O}_{3}$ and $\mathrm{CO}_{2}$ treatments reflects the transcriptional events, which may alter plant metabolism by modifying proteins and enhancing their susceptibility to "proteolytic degradation" leading to oxidative protein lesions.

The genetic interpretation of banding patterns constitutes an important aspect of isozyme electrophoresis. Electrophoretic banding patterns generated by MDH, AMY, LAP, EST, PER, and CAT isozymes showed distinct variations in response to different $\mathrm{CO}_{2}$ and $\mathrm{O}_{3}$ treatments compared to the control. Variations in the isozyme banding patterns can be interpreted in terms of the alleles and loci that encode the polypeptides forming different isozymes. These isozymatic variations may be correlated to changes or mutation in the nitrogenous base sequence of DNA that result in subsequent changes and substitution of amino acids and consequently, lead to a change in the net charge of a proteins consisted isozyme (Kumar et al., 2009). They may also be due to the interaction of a gene with oxidative stress induced by greenhouse gas treatment or to alterations in the conformation of the enzyme molecules, consequently altering the migration rate of proteins in an electric field, as well as their electrophoretic mobility, efficiency, and stability (Kumar et al., 2009). The electrophoretic zymogram profiles generated by six isozymes revealed multiple zymograms on different loci with different $R_{f}$ values and unequal intensities. Changes in the electrophoretic mobility of zymograms may result from changes in the encoding DNA sequences or from the different sizes and shapes of the affected isozyme molecules (Karaca, 2013). Additionally, amino acid substitutions induced by $\mathrm{CO}_{2}$ and $\mathrm{O}_{3}$ stress that do not involve charge differences can also 
affect the electrophoretic mobility of a protein by altering the tertiary structure of the isozyme (Karaca, 2013). Therefore, $\mathrm{R}_{\mathrm{f}}$ values can be a useful genetic biomarker for the detection of genetic variation and genotoxic stress induced by $\mathrm{CO}_{2}$ and $\mathrm{O}_{3}$.

The advantage of RAPD analysis, as used in this study, is that it provides information on structural changes that might have occurred across the entire genome in response to $\mathrm{CO}_{2}$ and $\mathrm{O}_{3}$ stress The results of the RAPD assay revealed distinctive changes in the RAPD banding patterns and DNA damage in $\mathrm{CO}_{2}$ and $\mathrm{O}_{3}$-treated T. aestivum compared to the controls. These changes occurred with respect to variation in the number of DNA bands, their sizes, intensities, the appearance of new bands (unique), and the loss of existing bands (non-unique). Variations in these parameters revealed high levels of DNA polymorphisms. The number of amplified DNA products may be due to the direction and number of base-pair sequences within the genome that are complementary to the primer sequence. Variations in the characteristic DNA banding pattern generated by RAPD analysis may be caused by structural changes within base-pair sequences of DNA between oligonucleotide primer binding sites under genotoxic stress caused by $\mathrm{CO}_{2}$ and $\mathrm{O}_{3}$ during DNA replication or gene expression (Kumar et al., 2009). Indeed, the gain/loss of RAPD bands, or differences in intensity may be related to DNA damage, nucleotide substitution within a target site, insertion or deletion of nitrogenous base sequences of a DNA-fragment, gene mutations, and/or structural rearrangements, which are induced by the genotoxic stressors $\mathrm{CO}_{2}$ and $\mathrm{O}_{3}$, affecting the primer sites and/or interpriming distances (Lal et al., 2011).

High levels of DNA polymorphism observed by RAPD in the present study may be due to heritable changes in the nucleotide sequences of treated DNA samples in coding and non-coding regions (Lal et al., 2011) or to structural changes in the genomic DNA that alter the distance between two annealing sites and delete an existing site of new one or to changes during gene expression (Dhakshanamoorthy et al., 2011). Conversely, the deletion or insertion of the amplified DNA regions, and changes in the nitrogenous base sequence that alter primer binding sites may lead to high levels of polymorphisms in the RAPD profile (Dhakshanamoorthy et al., 2011). Therefore, DNA polymorphisms are considered to be a suitable method for measuring patterns of genetic variation in response to $\mathrm{CO}_{2}$ and $\mathrm{O}_{3}$ treatments.

The main changes in the RAPD profiles observed in the present study were the appearance or loss of different DNA bands and variation in their intensities. The presence and absence of bands indicated a clear ability of $\mathrm{CO}_{2}$ and $\mathrm{O}_{3}$ stress to induce gene mutation, DNA damage, or alter base sequences of DNA during its replication in tested wheat plant cells. The appearance of new DNA bands (unique) may be due to the fact that some oligonucleotide priming sites become available to primers as a result of structural changes in the DNA sequence due to point mutations, breaks, transpositions, large deletions or additions, and/or homologous recombination, as suggested by Atienzar and Jha (2006) and Cansaran-Duman et al. (2015).

Conversely, the disappearance of some bands (non-unique) and loss of band intensity may be induced by genomic rearrangements, decreased point mutation, DNA damage in primer binding sites, or the interaction of DNA polymerase with damaged DNA, as suggested by Cansaran-Duman et al. (2015). In addition, the loss of DNA bands may be related to DNA damage (e.g., single- and double-strand breaks, modified bases, basic sites, oxidized bases, bulky adduct, and DNA-protein cross-links), and/or complex chromosomal rearrangements (Atienzar and Jha, 2006). The present study shows that the appearance and loss of DNA bands offers a useful biomarker assay for use in the detection of genotoxicity induced by $\mathrm{CO}_{2}$ and $\mathrm{O}_{3}$ stress. 
The alkaline comet assay (or single-cell gel electrophoresis) is a sensitive method for the detection of DNA lesions. Comet assay data revealed clear variations in the extent of nuclear DNA damage induced by $\mathrm{CO}_{2}$ and $\mathrm{O}_{3}$ stress in wheat samples compared to control samples. This DNA damage reflects the specific effects of $\mathrm{CO}_{2}$ and $\mathrm{O}_{3}$ on the nuclear DNA of treated samples, which resulted in the increased migration of DNA fragments (comet tail) from the nucleus (comet head). This indicates that $\mathrm{CO}_{2}$ and $\mathrm{O}_{3}$, on their own or in combination, and their metabolites inside wheat cells under irrigated and non-irrigated conditions, may generate various levels of oxidative DNA lesions through the interaction of ROS induced by these treatments with DNA molecules of the test plant. In addition to increased ROS levels, several types of DNA lesions may be induced by gaseous stress, such as DNA strand breaks (single and double), deletion or insertion of base pairs, pyrimidine dimers, cross-links, and base modification, such as alkylation and oxidation in addition to mismatch errors, which occur due to incomplete excision repair of DNA adducts (Olive and Banath, 2006). The appearance of comet tails in the alkaline method could be indicative of the presence of replication forks in S-phase cells as well as cells stressed by $\mathrm{CO}_{2}$ and $\mathrm{O}_{3}$ treatment, in which single-strand breaks lead to DNA damage.

The DNA lesions induced by $\mathrm{CO}_{2}$ and $\mathrm{O}_{3}$ stress in wheat nuclei, as observed in the present study, may lead to increased DNA migration and the loss of high levels of DNA as comet tails, which can reduce the stability of the plant genome resulting in various molecular and physiological effects, such as reduced protein synthesis leading to reduced growth and development of the whole plant, and consequently crop yield productivity. In the present study, DNA damage in $\mathrm{O}_{3}$-treated wheat, as measured by the comet assay, was clearly increased over the control and was higher than that observed in response to $\mathrm{CO}_{2}$ stress, on its own and in combination with $\mathrm{O}_{3}$. Therefore, it is concluded that elevated $\mathrm{CO}_{2}$ may ameliorate $\mathrm{O}_{3}$-induced oxidative DNA damage when they are used in combination. This may be due to reduced stomatal conductance as a result of elevated $\mathrm{CO}_{2}$ suppressing the entry of $\mathrm{O}_{3}$ through stomata (Mishra et al., 2013) or by increasing the levels of antioxidant defense in wheat cells which result in reducing high levels of ROS induced by $\mathrm{O}_{3}(\mathrm{Xu}$ et al., 2015). This conclusion is in contrast with that reported by Tai et al. (2010) who concluded that exposure to $\mathrm{O}_{3}$ in combination with $\mathrm{CO}_{2}$ increased levels of DNA damage above the background level as measured by the comet assay.

In conclusion, the current results demonstrated that protein, isozymes, and DNA have variable responses to elevated $\mathrm{CO}_{2}$ and $\mathrm{O}_{3}$, alone and in combination under irrigated and non-irrigated systems. As a result of oxidative damage in protein and DNA, wheat plants were more sensitive to $\mathrm{O}_{3}$, especially under NI systems. The most notable finding in this study was that elevated $\mathrm{CO}_{2}$ could ameliorate the negative impact of elevated $\mathrm{O}_{3}$ on proteins and DNA, when present in combination. This confirmed that $\mathrm{CO}_{2}$ may enhance the tolerance of wheat tissue to $\mathrm{O}_{3}$-induced oxidative stress by increasing the activity of the antioxidant defense system. Furthermore, the results of the current study demonstrated that crop wheat plants grown under elevated $\mathrm{CO}_{2}$ levels could be protected against $\mathrm{O}_{3}$-induced oxidative stress. Finally, it is concluded that protein and DNA biomarkers combined with a molecular cytogenetic technique (comet assay) should be used for the reliable estimation of genotoxicity following the exposure of economic crop plants to air pollutants.

Further studies investigating the genetic responses of other crop plants in response to $\mathrm{CO}_{2}$ and $\mathrm{O}_{3}$, and to other gases, are needed to ascertain how protein-based biochemical and DNA-based molecular technologies can be utilized to modify these responses through genetic manipulation, which may be valuable in the field of genetic and crop improvements. 


\section{Conflicts of interest}

The author declares no conflict of interest.

\section{ACKNOWLEDGMENTS}

The author would like to extend their sincere appreciation to the Deanship of Scientific Research at King Saud University for its funding of this research through the Research Group Project (\#RGP- 231).

\section{REFERENCES}

Abdelhaliem E, Abdullah H and Al-Huqail AA (2013). Oxidative damage and mutagenic potency of fast neutron and UV-B radiation in pollen mother cells and seed yield of Vicia faba L. Biomed. Res. Int. 2013: 824656.

Al-Huqail AA and Abdelhaliem E (2015). Evaluation of genetic variations in maize seedlings exposed to electric field based on protein and DNA markers. Biomed. Res. Int. 2015: 874906. http://dx.doi.org/10.1155/2015/874906

Atienzar FA and Jha AN (2006). The random amplified polymorphic DNA (RAPD) assay and related techniques applied to genotoxicity and carcinogenesis studies: a critical review. Mutat. Res. 613: 76-102. http://dx.doi.org/10.1016/j. mrrev.2006.06.001

Cansaran-Duman D, Altunkaynak E, Aslan A, Büyük İ, et al. (2015). Application of molecular markers to detect DNA damage caused by environmental pollutants in lichen species. Genet. Mol. Res. 14: 4637-4650. http://dx.doi. org/10.4238/2015.May.4.23

Dhakshanamoorthy D, Selvaraj R and Chidambaram ALA (2011). Induced mutagenesis in Jatropha curcas L. using gamma rays and detection of DNA polymorphism through RAPD marker. C. R. Biol. 334: 24-30. http://dx.doi. org/10.1016/j.crvi.2010.11.004

Dikilitas M, Kocyigit A and Yigit F (2009). A molecular-based fast method to determine the extent of DNA damages in higher plants and fungi. Afr. J. Biotechnol. 8: 3118-3127.

Ephratha JE, Timlinb DJ, Reddyb V and Bakerc J (2011). Irrigation and elevated carbon dioxide effects on whole canopy photosynthesis and water use efficiency in cotton (Gossypium hirsutum L.). Plant Biosystems 145: 202-215. http:// dx.doi.org/10.1080/11263504.2010.544108

Galani S, Naz F, Soomro F, Jamil I, et al. (2011). Seed storage protein polymorphism in ten elite rice (Oryza sativa L.) genotypes of Sindh. Afr. J. Biotechnol. 10: 1106-1111.

Georg-Kraemer JE and Cavalli SS (2003). Structural and regulatory differences in amylase isoenzymes in germinating Brazilian barley cultivars. Genet. Mol. Biol. 26: 69-75. http://dx.doi.org/10.1590/S1415-47572003000100012

Gjorgieva D, Kadifkova-Panovska T, Mitrev S, Kovacevik B, et al. (2012). Assessment of the genotoxicity of heavy metals in Phaseolus vulgaris L as a model plant system by Random Amplified Polymorphic DNA (RAPD) analysis. J. Environ. Sci. Health A. Tox. Hazard Subst. Environ. Eng. 47: 366-373. http://dx.doi.org/10.1080/10934529.2012.645784

Hailu HW, Kristiyanto DH, Alatawi ARA and Raqib SM (2014). Isozyme electrophoresis and morphometri Comparison of Reed (Imperata cylindrical) adaptation to different Altitudes. Int. J. Innov. Res. Sci. Eng. Technol. 3: 12387-12394.

Hojilla-Evangelista MP and Evangelista RL (2006). Effects of cooking and screw-pressing on functional properties of Cuphea PSR23 seed proteins. J. Am. Oil Chem. Soc. 83: 713-718. http://dx.doi.org/10.1007/s11746-006-5028-8

IPCC (2013). Summary for Policymakers. In: Climate Change 2013: The physical Science Basis. Contribution of Working group I to the Fifth Assessment Report of Intergovernmental Panel on Climate Change (Stocker TF, Qin D, Plattner GK, Tignor M, Allen SK, Bouschung J, Nauels A, Xia Y, Bex V and Midgley PM, eds.). Cambridge University Press, Cambridge, United Kingdom and New York, USA.

Johnson M, Janakiraman N, Chalini K, Narayani M, et al. (2012). Studies on developmental variation of isoperoxidase and protein profile of Zea mays L. J. Stress Physiol. Biochem. 8: 16-23.

Juchimiuk J, Gnys A and Maluszynska J (2006). DNA damage induced by mutagens in plant and human cell nuclei in acellular comet assay. Folia Histochem. Cytobiol. 44: 127-131.

Karaca M (2013). Isozymes as biochemical markers in plant genetics. Int. J. Agric. Sci. 3: 851-861.

Kit YS and Chandran S (2010). A simple, rapid and efficient method of isolating DNA from Chokanan mango (Mangifera indica L.). Afr. J. Biotechnol. 9: 5805-5808.

Kumar OA and Tata SS (2010). SDS-Page Seed Storage Protein Profiles in Chili Peppers (Capsicum L.). Not. Sci. Biol. 2: 86-90.

Genetics and Molecular Research 15 (2): gmr.15028736

CFUNPEC-RP www.funpecrp.com.br 
Kumar P, Gupta VK, Misra AK, Modi DR, et al. (2009). Potential of molecular markers in plant biotechnology. Plant Omics J. 2: 141-162.

Laemmli UK (1970). Cleavage of structural proteins during the assembly of the head of bacteriophage T4. Nature 227: 680-685. http://dx.doi.org/10.1038/227680a0

Lal S, Mistry KN, Shah SD, Thaker R, et al. (2011). Genetic diversity assessment in nine cultivars of Catharanthus roseus from Central Gujarat (India) through RAPD, ISSR and SSR markers. J. Res. Biol. 1: 667-675.

Liao H, Zhang F, Xiaosong H and Liao X (2011). Effects of high-pressure carbon dioxide on proteins and DNA in Escherichia coli. Microbiology 157: 709-720. http://dx.doi.org/10.1099/mic.0.046623-0

Majumder DAN, Hassan L, Rahim MA and Kabir MA (2012). Analysis of genetic diversity in mango (Mangifera indica L.) using isozymetic polymorphism. African J. Biotechnol. 11: 15310-15323.

Maluszynska J and Juchimiuk J (2005). Plant genotoxicity: A molecular cytogenetic approach in plant bioassays. Arh. Hig. Rada Toksikol. 56: 177-184.

Mishra AK, Rai R and Agrawal SB (2013). Individual and interactive effects of elevated carbon dioxide and ozone on tropical wheat (Triticum aestivum L.) cultivars with special emphasis on ROS generation and activation of antioxidant defense system. Indian J. Biochem. Biophys. 50: 139-149.

Mondini L, Noorani A and Pagnotta MA (2009). Assessing plant genetic diversity by molecular tools. Diversity 1: 19-35. http://dx.doi.org/10.3390/d1010019

Monneveux P, Jing R and Misra SC (2012). Phenotyping for drought adaptation in wheat using physiological traits. Front Physiol. 3: 429. http://dx.doi.org/10.3389/fphys.2012.00429

Mouemar AA and Gasquez J (1983). Environmental conditions and isozyme polymorphism in Chenopodium album L. Weed Res. 23: 141-149. http://dx.doi.org/10.1111/j.1365-3180.1983.tb00532.x

Mulchi CL, Slaughter L, Saleem M, Lee EH, et al. (1992). Growth and physiological characteristics of soybean in opentop chambers in response to ozone and increased atmospheric CO2. Agr. Ecosyst. Environ. 38: 107-118. http://dx.doi. org/10.1016/0167-8809(92)90172-8

Olbrich M, Gerstner E, Welzl G, Winkler JB, et al. (2009). Transcript responses in leaves of ozone-treated beech saplings seasons at an outdoor free air model fumigation site over two growing seasons. Plant Soil 323: 61-74. http://dx.doi. org/10.1007/s11104-009-0129-4

Olive PL and Banath JP (2006). The Comet assay: a method to measure DNA damage in individual cells. Nat. Prot. 1: 23-29. http://dx.doi.org/10.1038/nprot.2006.5

Padmanaban V, Karthikeyan R and Karthikeyan T (2013). Differential expression and genetic diversity analysis using alpha esterase isozyme marker in Ocimum sanctum L. Acad. J. Plant Sci. 6: 1-12.

Ravindranath SD and Fridovich I (1975). Isolation and characterization of manganese containing SOD from yeast. $J$. Biochem. 250: 6107-6112.

Sadasivam S and Manickam A (1992). Biochemical methods for Agricultural Science. Chapter 4.2 Wiley Eastern Ltd. and Tamil Nadu Agriculture University, Coimbatore, India. 139.

Saraswati R, Matoh T, Phupaibul P, Lumpkin T, et al. (1993). Identification of Sesbania species from electrophoretic patterns of seed proteins. Trop. Agr. 70: 282-285.

Shikazono N, Suzuki C, Kitamura S, Watanabe H, et al. (2005). Analysis of mutations induced by carbon ions in Arabidopsis thaliana. J. Exp. Bot. 56: 587-596. http://dx.doi.org/10.1093/jxb/eri047

Sliwinska E, Pisarczyk I, Pawlik A and Galbraith DW (2009). Measuring genome size of desert plants using dry seeds. Botany 87: 127-135. http://dx.doi.org/10.1139/B08-120

Tai HH, Percy KE and Karnosky DF (2010). DNA damage in Populus tremuloides clones exposed to elevated $\mathrm{O}_{3}$. Environ. Pollut. 158: 969-976. http://dx.doi.org/10.1016/j.envpol.2009.10.005

Tripathi R and Agrawal SB (2012). Effects of ambient and elevated level of ozone on Brassica campestris L. with special reference to yield and oil quality parameters. Ecotox. Environ. Safe. J. 85: 1-12. http://dx.doi.org/10.1016/j.ecoenv.2012.08.012

Ventura L, Giovannini A, Savio M, Donà M, et al. (2013). Single Cell Gel Electrophoresis (Comet) assay with plants: Research on DNA repair and ecogenotoxicity testing. Chemosphere 92: 1-9. http://dx.doi.org/10.1016/j.chemosphere.2013.03.006

Williams JGK, Kubelic AR, Livak KJ, Rafalski JA, et al. (1990). DNA polymorphisms amplified by arbitrary primers are useful as genetic markers. Nucleic Acids Res. 18: 6531-6535. http://dx.doi.org/10.1093/nar/18.22.6531

Wilson K and Walker J (2005). Principles and Techniques of Biochemistry and Molecular Biology. Cambridge University Press, Cambridge.

Wroblewitz S, Huther L, Manderscheid R, Weigel HJ, et al. (2013). The effect of free air carbon dioxide enrichment and nitrogen fertilization on the chemical composition and nutritional value of wheat and barley grain. Arch. Anim. Nutr. 67: 263-278. http://dx.doi.org/10.1080/1745039X.2013.821781

$\mathrm{Xu}$ Z, Jiang Y and Zhou G (2015). Response and adaptation of photosynthesis, respiration, and antioxidant systems to elevated $\mathrm{CO}_{2}$ with environmental stress in plants. Front. Plant Sci. 2015; 6: 1-17. 